\title{
Enhanced self-control for the prevention of pornography of student in senior high school
}

\author{
Ahsanul Hafizh ${ }^{1}$, Firman ${ }^{2}$, Netrawati ${ }^{3}$ \\ 1,2,3 Universitas Negeri Padang \\ *Corresponding author, e-mail: ahsanulhafizh4@gmail.com
}

\begin{abstract}
The lack of students' self-control led to the emergence of pornography. The phenomenon of pornography is a general term that refers to sexually explicit material that may be softcore or hardcore and can also be referred to as things that attempt to stimulate and increase sex drive with text and images. Self-control is the ability to organize, guide, regulate, and direct forms of behavior that can lead to positive consequences. The purpose of this study was to describe students' self-control at SMA $\mathrm{N} 1$ Merbau. This research uses descriptive analysis. The research sample consisted of 128 students who were taken using purposive sampling technique. The instrument used was "Self-control scale in preventing pornography" with a reliability value of (0.888). The results showed that: most of the students as many as $(65.6 \%)$ of the students had "moderate" self-control in the prevention of pornography, then a small proportion of students $(2.3 \%)$ of students had "low self-control". "In the prevention of pornography. Furthermore, as many as (5.5\%) students had "very high" self-control in preventing pornography and as many as (26.6\%) students had "high" self-control in preventing pornography. The results of the study generally showed that students' selfcontrol was in the medium category with a percentage of $65.6 \%$ and it needed to be improved in order to prevent pornography. The results of this research can be used as a basis for counseling teachers in providing guidance and counseling services to prevent student pornographic behavior in schools.
\end{abstract}

Keywords: Self-Control, Prevention of Pornography

How to Cite: Hafizh, A., Firman, F., Netrawati, N. (2021). Enhanced self-control for the prevention of pornography of student in senior high school. International Journal of Applied Counseling and Social Sciences, 2 (2): pp. 134-139, DOI: http://doi.org/10.24036/005426ijaccs

This is an open access article distributed under the Creative Commons 4.0 Attribution License, which permits unrestricted use, distribution, and reproduction in any medium, provided the original work is properly cited. (2021 by Author

\section{Introduction}

Pornography is things that try to stimulate and increase sex drive with writing and images (Sofyan, 2014). The effect of exposure to pornography is not only in the form of knowledge about pornography, but also reaches the affective aspect, namely the tendency to behave 
(Nafikadini, 2013). In line with this opinion, pornography can also have a negative effect on changing attitudes or behavior, adolescents tend to imitate the behavior they see, to the effect of addiction to pornography (Anisah, 2016). Pornography can be prevented by having a strong self-control, Berk explained that self-control is the ability of an individual to withstand a momentary desire or urge that is contrary to behavior and not in accordance with social norms (Gunarsa, 2006). There is a very significant relationship between self-control and juvenile delinquency, which means that the higher self-control, the lower the tendency for juvenile delinquency (Evi Aviyah, 2014), low self-control has a significant direct effect on the use of pornography (Buzell, 2016).

Pornography attacks all levels of society and even countries, Sweden is one of them, as a developed country, of course the phenomenon of pornography is very easy to find, based on research conducted in that country by Wallmyr on 876 respondents consisting of 555 women and 321 men who are in the age range of $15-20$ years, it was found that $98.9 \%$ of men and $73.5 \%$ of women had viewed pornographic content. The reason most often stated by male respondents was to be aroused and masturbate, and the reason for female respondents was to fulfill their curiosity about sexuality (Wallmyr \& Welin, 2016). In Indonesia, data published by the Indonesian Child Protection Commission (KPAI) where from 2011 to 2016, the number of child victims of pornography and online crime in Indonesia had reached 1,809 cases, which in numbers continued to increase every year, although in 2016 it had decreased.

Furthermore, in a study conducted in the city of Pontianak in 2008, the results showed that of 331 respondents, $19.8 \%$ were in the addiction stage (Supriati \& Fikawati, 2009). Adolescents who have accessed pornography have a vulnerability in the tendency to have free sex behavior compared to adolescents who have never accessed pornographic content (Suwarsi, 2016).

Pornography has a negative impact on its users, especially adolescents who are still in the process of forming their identity and self-concept, adolescents who are still imitators make everything they feel as knowledge and often without proper control they try to imitate this, besides this impact, pornography is also can have a devastating effect on the user in the form of more severe brain damage than drugs. If drugs can damage three parts of the brain, pornography can damage five parts of the brain, Pre Frountal Cortex (PFC) is the most damaged part of the brain due to pornography, which makes it difficult for a person to plan, control lust and emotions and make decisions and various role and executive of the brain as a controller of impulses (Burlian, 2016). In addition to providing knowledge that is too early to adolescents, pornography can also have a very bad effect on users ranging from depression, sexual fantasies, and hypersexuality (Brand, Snagowski, Laier, \& Maderwald, 2016).

Based on the previous explanation, the authors are interested in conducting research on self-control for the prevention of pornography because pornography not only provides inaccurate knowledge but also has adverse effects on psychological health such as (depression, sexual fantasies and sexual hyper) and for physical health such as masturbation and masturbation and pre-frountal cortex (PFC) nerve cell damage. So that with this study the public will increasingly know how dangerous the effects of pornography are for health, furthermore with the results of this study it is hoped that it can also be used by interested parties such as teachers, parents, observers of children so that more caring, open space for discussion, and socialization of appropriate sexual knowledge to adolescents. 


\section{Method}

The method in this research uses quantitative methods with descriptive analysis (Kothari, 2004). Quantitative research method is a method that provides a picture in the form of numbers and then analyzed using statistics (Creswell, 2009). The population in this study were students of SMA N 1 Merbau, totaling 128 students of class XI. The sample of this study was 36 students taken with the Slovin formula followed by using purposive random sampling.

The instrument used in this study was the "Self-Control Scale in the Prevention of Pornography" in the form of a Likert scale. This research was conducted directly to students by administering "Self-control scale in preventing pornography" and explaining the instructions for filling out the instrument to students. Test the validity of the instrument using the Product Mement Correlation formula. "Student self-control scale in preventing pornography" with a reliability value $(0.888)$. The data were analyzed using descriptive analysis. This research data was processed using the help of statistical products and service solutions (SPSS) version 20.00. Descriptive analysis techniques were used to describe the level of student self-control in preventing pornography.

\section{Results and Discussion}

Based on the results of data analysis related to the level of self-control in preventing pornography at SMA 1 Merbau, the following description.

Table 1. The Results of Self-Control Questionnaire Analysis in the Prevention of Pornography $(\mathrm{N}=128)$

\begin{tabular}{ccccc}
\hline INTERVAL & $\mathbf{\%}$ & Cat & f & $\mathbf{\%}$ \\
\hline $\mathbf{1 1 0 - 1 3 6}$ & $84 \%-100 \%$ & $\mathrm{ST}$ & 7 & 5,5 \\
$\mathbf{8 7 - 1 0 9}$ & $68 \%-83 \%$ & $\mathrm{~T}$ & 34 & 26,6 \\
$\mathbf{6 4 - 8 6}$ & $52 \%-67 \%$ & $\mathrm{~S}$ & 84 & 65,6 \\
$\mathbf{4 1 - 6 3}$ & $36 \%-51 \%$ & $\mathrm{R}$ & 3 & 2,3 \\
$\leq \mathbf{4 0}$ & $\leq 35 \%$ & $\mathrm{SR}$ & 0 & 0,0 \\
& Total & & 128 & $\mathbf{1 1 2}$ \\
\hline
\end{tabular}

Based on the analysis of table 3 above, it is known that most of the students, namely as many as $84(65.6 \%)$ of students have "moderate" self-control in preventing pornography, then a small proportion of students as many as $3(2.3 \%)$ of students have control low self-esteem in the prevention of pornography. Furthermore, as many as 7 (5.5\%) students had "very high" self-control in preventing pornography and as many as $34(26.6 \%)$ students had "high" selfcontrol in preventing pornography. Thus it can be concluded that some of the students need counseling services related to increasing self-control. Therefore, it is necessary to carry out a special strategy that is used to increase students' self-control in preventing pornography. 
Table 2. Results of Self-Control Questionnaire Analysis in the Prevention of Pornography by Indicators

\begin{tabular}{|c|c|c|c|c|c|c|c|c|c|c|}
\hline \multirow[t]{2}{*}{ No } & Indicator & Item & \multicolumn{4}{|c|}{$\Sigma$} & \multirow[t]{2}{*}{ Mean } & \multirow[t]{2}{*}{$\%$} & \multirow[t]{2}{*}{ SD } & \multirow[t]{2}{*}{ Kat. } \\
\hline & & & స్ల్ర & $\sum_{\Sigma}^{\star}$ & $\Sigma$ & & & & & \\
\hline 1 & $\begin{array}{l}\text { Ability to } \\
\text { organize } \\
\text { implementat } \\
\text { ion }\end{array}$ & 6 & 30 & 30 & 11 & 2596 & 20,28 & 67,68 & 3,34 & $S$ \\
\hline 2 & $\begin{array}{l}\text { Ability to } \\
\text { regulate } \\
\text { stimulus }\end{array}$ & 4 & 20 & 20 & 8 & 1669 & 13,04 & 65,2 & 2,448 & $S$ \\
\hline 3 & $\begin{array}{l}\text { Ability to } \\
\text { obtain } \\
\text { information }\end{array}$ & 4 & 20 & 19 & 8 & 1540 & 12,03 & 60,16 & 2,248 & $S$ \\
\hline 4 & $\begin{array}{l}\text { Ability to do } \\
\text { assessment }\end{array}$ & 6 & 30 & 30 & 11 & 2419 & 18,92 & 63,07 & 3,315 & $S$ \\
\hline 5 & $\begin{array}{l}\text { Individual } \\
\text { ability to } \\
\text { select and } \\
\text { determine } \\
\text { desired } \\
\text { goals }\end{array}$ & 7 & 35 & 35 & 15 & 2997 & 23,48 & 67,08 & 4,307 & $S$ \\
\hline & Total & 27 & 135 & 134 & 53 & 11221 & 87,66 & 64,94 & 11,86 & $\mathrm{~S}$ \\
\hline
\end{tabular}

The results of the data analysis above show that overall student self-control is in the medium category with a percentage of $64.94 \%$ which means that students already have the ability to control themselves in their social groups which is quite good, but still needs to be improved again as an effort to prevent student exposure to pornography. . From the results of the analysis of the table above also shows that the indicator of self-control related to "the ability to manage implementation" has the highest percentage of $67.68 \%$ in the medium category. Meanwhile, the indicator of self-control related to "the ability to obtain information" obtained the lowest percentage of $60.16 \%$, which means that the ability of students to regulate implementation (regulated administration), which is the ability to control situations or circumstances in life related to pornography, can be categorized as quite good, individuals with good self-control abilities will certainly be able to regulate behavior by using their abilities, then the ability to obtain information (information again) also needs to be improved, because the information that individuals have about a situation will make the individual able to overcome the situation through objective considerations. Thus it can be concluded that some of the students need counseling services related to increasing self-control. Therefore, it is necessary to carry out a special strategy that is used to increase students' self-control in preventing pornography

Pornography can occur due to various factors, ranging from low self-control in individuals so that individuals tend to follow desires without internal control (Buzzell, Foss, \& Middleton, 2006). Furthermore, in a study conducted in Bandung on junior high school (SMP) students, it was found that adolescents who have low self-control tend to use cybersex as an outlet for the problems they face, thus making cybersex a solution if they experience problems (Dewangga \& Rahayu, 2010). Furthermore, in a study conducted in Samarinda, it was 
concluded that good self-control in adolescents will be able to make adolescents able to avoid negative behavior and contrary to values and norms (Khairunnisa, 2013)

Apart from low self-control, the phenomenon of pornography can also occur because it is so easy to access and obtain pornography via the internet (Duffy, Dawson, \& das Nair, 2016). The absence of parental supervision and the permissive attitude or parenting of parents (Hendrik, Soetjiningsih, \& Kristijanto, 2016). As well as the lack of student information and understanding about pornography and sexuality, so that teenagers use pornography as a vehicle to fulfill their needs for sexual knowledge (Wallmyr \& Welin, 2016).

The problem of pornography is a very complex problem and needs a comprehensive solution, which means that the problem of pornography is not sufficiently resolved by simply giving punishment to the community, especially students who do it, but it is more appropriate if students are given education to build their awareness that this knowledge is still inadequate. they know early (Wati, 2013). Schools as a place for students to learn a variety of knowledge, should have activities to facilitate students and equip students with appropriate sexual knowledge through sexual education (sex education), so that issues related to this knowledge can be discussed especially regarding pornography and the negative effects it causes, so that students have sufficient understanding of adolescent sexuality (Baker, 2016).

Based on this opinion, of course it can be concluded that the right way of prevention is to provide the right information to individuals, so that individuals can make this knowledge into consideration in acting and material for good and bad considerations so that the control function in self (Self Control) can run smoothly. good. Providing appropriate information to adolescents is of course very necessary, because with this information it can be a consideration for adolescents in making decisions. Based on Piaget's cognitive theory which says that every individual has an interest in the world and is actively looking for information that can help them understand the world, or in other words, the interactions carried out will lead individuals to cognitive development (Ibda, 2015). In line with this, in self-control, Averill argues that in self-control there is an aspect of cognitive control which is a person's way of interpreting, assessing and combining an event in a cognitive framework, which means managing information as material for individual consideration to anticipate a situation or event. objectively (Talib, 2010).

\section{Conclusion}

Pornography is a disclosure or erotic behavior such as in the form of books, pictures, in films that are intended to arouse sexual arousal. Self-control is the ability to compose, guide, organize, and direct forms of behavior that can lead to positive consequences. dri control is one of the factors that influence the prevention of pornography. In general, it can be concluded that the level of self-control of students is in the medium category. The higher the level of student self-control, the less pornography among students in school will be. Efforts are made to improve student pornography prevention by providing guidance and counseling services related to pornographic materials and student self-control.

\section{References}

Anisah, N. (2016). Efek Tayangan Pornografi di Internet Pada Perilaku Remaja di Desa Suka Maju Kecamatan Tenggarong Seberang. eJournal Ilmu Komuunikasi, 2016, 4 (1) : 115-.124 ISSN 2355-5408, Ejournal.ilkom.fisip-Unmul.ac.id @ Copyright 2016, 4(1), 115-124. 
Baker, K. E. (2016). Online pornography - Should schools be teaching young people about the risks? An exploration of the views of young people and teaching professionals. Sex Education, 16(2), 213-228. https://doi.org/10.1080/14681811.2015.1090968

Brand, M., Snagowski, J., Laier, C., \& Maderwald, S. (2016). Ventral striatum activity when watching preferred pornographic pictures is correlated with symptoms of Internet $\begin{array}{llll}\text { pornography } \quad \text { addiction. } & \text { NeuroImage, 224-232. }\end{array}$ https://doi.org/10.1016/j.neuroimage.2016.01.033

Buzzell, T., Foss, D., \& Middleton, Z. (2006). Explaining Use Of Online Pornography: A Test of Self-Control Theory and Opportunities for Deviance. Journal of Criminal Justice and Popular ..., 13(2), 96-116.

Creswell, J. W. (2009). Research design qualitative, quantitative and mixed methods approaches. Amerika: Sage Publications.

Dewangga, L. K., \& Rahayu, M. S. (2010). Hubungan antara kontrol diri dengan Cybesexual Addiction pada siswa SMP di Orange-Net Bandung. Prosiding Psikologi, ISSN : 2460-6448, 137-143.

Duffy, A., Dawson, D. L., \& das Nair, R. (2016). Pornography Addiction in Adults: A Systematic Review of Definitions and Reported Impact. Journal of Sexual Medicine, 13(5), 760-777. https://doi.org/10.1016/j.jsxm.2016.03.002

Hendrik, D., Soetjiningsih, C. H., \& Kristijanto, A. I. (2016). Religiusitas, Pajanan Media Pornografi, Dan Pola Asuh Permisif Orangtua Sebagai Prediktor Perilaku Seksual Remaja.

Ibda, F. (2015). PerkembanganTeori Kognitif: Jean Piaget. Jurnal Intelektualita, 3(1), 27-38.

Khairunnisa, A. (2013). Hubungan Religiusitas Dan Kontrol Diri Dengan Perilaku Seksual Pranikah Remaja Di Man 1 Samarinda. eJounal Psikologi Fisip Unmul, 1(2), 220-229.

Kothari, C. R. (1990). Research methodology methods and technique. Jaipur (India).

Nafikadini, I. (2013). Efek Paparan Pornografi Tehadap Aktivitas Seksual Pranikah Mahasiswa Universitas Jember. Universitas Jember, (37).

Supriati, E., \& Fikawati, S. (2009). Efek Paparan Pornogafi Pada Remaja SMP Negeri Kota Pontianak Tahun 2008 Effect of Pornography Exposure on Junior High School Teenagers of Pontianak in 2008. Sosial Humaniora, 13(1), 48-56.

Suwarsi. (2016). Analisis Faktor Penyebab Perilaku Seksual Pranikah pada Remaja di Desa Wedomartani Sleman Yogyakarta. Jurnal Ners Dan Kebidanan Indonesia, 4(1), 39. https://doi.org/10.21927/jnki.2016.4(1).39-43

Wallmyr, G., \& Welin, C. (2016). Young people, pornography, and sexuality: sources and attitudes. The Journal of School Nursing, 22(5), 290295.https://doi.org/10.1177/10598405060220050801

Wati, F. A. (2013). Persepsi Remaja Tentang Film Porno Studi Kasus Di Smk Nuri Samarinda: Perception of Teenagers about Porn Movies: A Case Study in SMK Nuri Samarinda. eJournal Sosiatri-Sosiologi, 2013 ISSN 0000-0000, Ejournal.sos.fisip-Unmul.org (C) Copyright 2013, 1(3), 1-10. 